\title{
Opus postumum
}

[Zbiór IV, Oktaventwurf]

Po st ęp (progressus) w wiedzy, rozpatrywanej jako nauka w ogóle, rozpoczyna się od zebrania składników nauki, a następnie odnalezienia sposobu, w jaki moją one zostać (systematycznie) uporządkowane. Podział tego zadania na naukę o elementach i naukę o metodzie ${ }^{1}$ stanowi najwyższy z możliwych podziałów, z czego pierwsza stanowi pojęcia, a druga sposób posługiwania się nimi [die Anordnung], by dzięki temu uzasadnić całość nauki.

Przejście (transitus) od jednej do innej formy wiedzy musi być krokiem (passus), a nie skokiem (saltus). To znaczy nauka o metodach wymaga, aby przejści e od metafizycznych podstaw przyrodoznawstwa do fizyki dokonało się od danych a priori pojęć przyrody do pojęć empirycznych, dostarczających wiedzy empirycznej. Przy czym będzie tu zasadą (zgodnie z żartobliwym powiedzeniem pewnego filozofa), by postępować jak słonie, które ani jednej ze swoich czterech nóg nie przesuną do przodu dopóki nie poczują,

${ }^{1}$ [Zachodzi tu gra słów, z której wynika, że składniki (elementy) wiedzy są przedmiotem osobnej nauki, innej niż metody uzyskiwania wiedzy, do których odnosi się nauka o metodach (metodologia).] 
że trzy pozostałe mocno tkwią w miejscu. Wszelkie siły fizyczne są jednak zawarte w pojęciu ruchu jako przyczyny sprawczej, której oddziaływanie jest jednocześnie odczuwalne i jako składnik [Element] doświadczenia opiera się na empirycznym [pojęciu ruchu]; ich przyczyna nie może być dana a priori, w odróżnieniu od formy rozmaitych relacji, w jakich musi on wystąpić, aby mógł działać.

[dolny margines]

Przyciąganie i odpychanie, obydwa jako siły powierzchniowe (cohaesio et expansio)

Przyciąganie i odpychanie, obydwa jako siły przenikające ciała (gravitatio et caloricum)

Płynna i stała materia

Rozpuszczanie w płynie na jednorodne części (solutio)

Rozpad na nierówne [części] (decompositio)

Ruch swobodnie postępujący i wibracyjny (światło)

O spójności [Cohäsion] w odróżnieniu od przylegania [Adhäsion] (continui albo interrupti) jednorodnych, a nie stopionych materii pośrednic z ą c y c h, np. wody albo stykających się gładkich powierzchni ciał stałych.

Wszelka materia jako taka może zostać poznana tylko za pośrednictwem doświadczenia (a mianowicie jako pewne kwantum w przestrzeni), tylko jeśli jest ono wprawiane w ruch przez zewnętrzną siłę ciała, którego wpływ je przenika, tj. przez ciążenie, a dokładniej przemienne powszechne p r z y ci ą g a n i e na odległość, grawi t a cję. Gdyby jednak materia była ekspansywna i jednocześnie ni e u chw yt na [incoercibel] (jak się sądzi o materii [XXI 388] magnetycznej, a po części także o eterze w ogólności), wtedy byłaby ona także niechybnie ni eważka [i mponderabel], tzn. za pomocą żadnego doświadczenia nie dałoby się poznać ani jej, ani jej ciężaru. Ci ięż a r [Ponde rosität] jest ilością materii poznawalną dzięki jej stopniowaniu, i zmienia się w stosunku odwrotnie proporcjonalnym do kwadratu odległości dzielącej ciążące ku sobie ciała: im dalej od Ziemi, tym jest mniejszy. Materia ciepła, ponieważ jest materią ekspansywną, a jednocześnie nieuchwytną [incoërcibel], musi więc być traktowana - tak jak materia magnetyczna - jako materia nieważka, chociaż ta ostatnia nie w sposób absolutny, ale jedynie względny, w odniesieniu do wszystkich materii poza żelazem. 


\section{5}

Fizyka sama w sobie nie zawiera

jeszcze żadnego szczególnego przejścia od po prostu mechanicznej

do organicznej (to znaczy opartej na pojęciu celów) przyrody,

które to [przejście] oraz zgodnie z którym [to przejściem] można byłoby przyczynowo wytłumaczyć je [tzn. cele]; przekracza zdolność pojmowania ludzkiego rozumu

Ponieważ fizyka sama dokonuje tu skoku, a mia nowicie [skoku] ku przyrodzie, która tylko daje się pomyśleć jako możliwa za sprawą celów, ponieważ nie jesteśmy w stanie przerzucić żadnego mostu, by z jednego brzegu przedostać się na drugi

O mechanicznym połączeniu pojedynczych materii świata

2

O mechanicznym formowaniu się wszechświata [Weltgebäude]

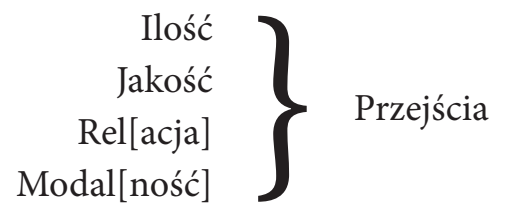

Ponieważ siła spajająca ciała stałe jest skończona, więc grubość przyciąganych warstewek musi być nieskończenie mała, gdyż w przeciwnym razie takie ciało albo nić w ogóle nie mogłyby zostać rozerwane. W efekcie przyciąganie w ogóle nie wychodzi poza powierzchnię styczności.

Jeśli wyobrazimy sobie pewną ilość wody [Wassermasse] swobodnie unoszącą się w powietrzu, na którą działa zwyczajne ciśnienie atmosferyczne, wówczas nacisk ten nie jest w stanie zmienić kształtu [masy wody]. W równie małym stopniu może się to dokonać za sprawą jej własnego przyciągania, które zawsze skierowane jest prostopadle do powierzchni, która w tym samym kierunku stawia mu opór. Nie może się więc dokonać za sprawą martwej, lecz wyłącznie żywej siły (uderzenia).

$[\ldots]$ 
[XXI 402]

Pojęcie przyrodoz naw st wa (philosophia naturalis) jest systematycznym przedstawieniem praw ruchu przedmiotów zewnętrznych w przestrzeni i czasie, jeśli tylko mogą one zostać poznane a priori, a więc w sposób konieczny. Albowiem poznanie tego, co przypadkowe jedynie za pośrednictwem doświadczenia odnosi się do zdobytego poznania tych zewnętrznych zjawisk; nie jest więc filozofią, ale jedynie agregatem postrzeżeń, których zupełność, jako pewien system, jest niemniej jednak przedmiotem filozofii.

Naczelny podział przyrodoznawstwa [Naturwisseschaft] pod względem jego treści nie może być innym podziałem, aniżeli podział na m e t a fi z y c z ne podstawy [przyrodoznawstwa], które w całości oparte są na pojęciach relacji ruchu i spoczynku zewnętrznych przedmiotów oraz na fi z y kę, która systematycznie porządkuje treść poznania odnoszącego się do doświadczenia owych przedmiotów, a która - jak już powiedziano - ma za zadanie dążyć do z u p ełn e go obliczenia jego elementów, jednak nie można liczyć, że dokona tego w sposób pewny.

Niemniej jednak relacja jednego rodzaju poznania do innego, które ani nie jest całkowicie oparte na zasadach a priori, ani na zasadach empirycznych, [XXI 403] może być ustanowiona jedynie jako przejście jednego do drugiego. A mianowicie [może ona pokazywać], w jaki sposób możliwe jest dla nas zebranie i uporządkowanie elementów opartej na doświadczeniu teorii przyrody i doprowadzenie do kompletności ich systematycznej klasyfikacji. W ten sposób uzyskuje się fi zy kę, która stanowi względnie zupełną całość; które [to przejście] nie jest ani czystą metafizyką przyrody, ani fizyką, ale jedynie przejściem tej pierwszej do drugiej i krok, który łączy obydwa brzegi.

Fizyka przyrody mineralnej albo organicznej. Tylko tę pierwszą rozważamy na podstawie zasady a priori.

[następna strona, górny margines]

W ciałach stałych, jeśli uprzednio były płynne, tworzą się włókna, płytki i bloki. 
[tekst główny]

\section{1. \\ Ilość materii}

Staje się ona [tj. ilość] znana, tylko jeśli ulega poruszeniu w masie, albo $\mathrm{w}$ wyniku uderzenia, nacisku lub pociągnięcia (nacisk nie w masie, ale w wyniku stopniowego oddziaływania płynu na ciało [Gegenstand], traktowane jest jak jedno uderzenie). Uderzenie jest siłą żywą, nacisk i pociąganie jest siłą martwą. Pierwsza $\mathrm{z}$ nich jest nieskończenie wielka w porównaniu z drugą.

Każda materia jako taka musi być pomyślana jako sama w sobie ważka $\mathrm{z}$ powodu powszechnego ciążenia w świecie, choć nie jest ono [powszechne ciążenie] fizycznie ważkie.

[Staje się ona znana], jeśli jest przyciągająca w odniesieniu do wewnętrznych cząstek, jednych wobec innych, albo odpychająca, i gdy w obu przypadkach jest ona: (1) pierwotna, a mianowicie bez tej ostatniej żadna przestrzeń nie byłaby wypełniona, tak jak bez tej pierwszej żadna ilość materii nie byłaby poznawalna: grawitacja; (2) wtórna, dzięki ciepłu.

[Materia] płynna i stała. Obydwie w spójności materii.

W szczególności wskutek rozpuszczania materii pod wpływem ciepła, którego materia nie jest ani płynna, ani stała, ale wywołuje jedną, jak i drugą.

Czy promień światła może być zawracany przez powszechne ciążenie.

$\mathrm{O}$ rozpuszczaniu materii w światło i eter, a zatem o pierwszym formowaniu [materii] wskutek przyciągania [eteru]. Regeneracja.

Relacja

Spójność, tzn. przyciąganie w styczności i przyciąganie na odległość (powszechne ciążenie [Weltattraction]), gwałtowne skupianie się (crystalisatio) w przypadku sztywnienia płynu, gdy woda albo ciepło szybko ulegają odparowaniu.

Punkt fizyczny. Coś nierzeczywistego [Unding]. 
4.

Modalność

Ruch zachodzący momentalnie: (a) jako ruch czysto możliwy, ale powstrzymany (siła martwa), (b) jako [ruch] rzeczywisty, ruch w tej samej chwili przyspieszony albo jednostajnie opóźniony, (c) jako [ruch] konieczny, w ruchu wywołanym spadaniem $\mathrm{z}$ określonej wysokości, nie w wyniku zwiększenia stopnia momentu [pędu], ale jedynie w wyniku [zwiększenia stopnia] ruchu za pośrednictwem momentu [pędu], i dalej koniecznie powiązany z tym ostatnim i osiągający kres w jego wzroście. Tak samo niezmienność ciążenia, pozostaje jako konieczność przy tym samym stopniu ruchu. Nie stopniowe wygasanie [ruchu], jak to może się przedstawiać w przypadku istnienia duszy.

[Po prawej stronie dodatku, poniżej]

O przyrodzie jako o sztuce: (1) bez określonego celu, (2) jako dla innych istot naturalnych, (3) jako celu rzeczy samych w sobie. Istoty uorganizowane.

\author{
Dodatek \\ O całości przyrody \\ w przestrzeni i w czasie
}

Ludzki rozum nie jest wystarczający, by w badaniu przyrody dokonać przejścia od metafizyki do fizyki. Tkwi w nim pewien instynkt - który nawet [XXI 405] jeśli jest całkowicie bezowocny, nie jest przecież powodem do wstydu - do przekraczania tej ostatniej [tj. fizyki] oraz fantazjowania na temat jakiejś hiperfizyki, a także odnoszenia się do całej przyrody w jeszcze większym zakresie, a mianowicie $\mathrm{w}$ świecie idei, według projektów odniesionych do celów moralnych, w taki sposób, że Bóg i nieśmiertelność duszy (ten pierwszy jako natura naturans, ta ostatnia zaś jako natura naturata) mogą obejmować całkowicie jedynie krąg naszego dążenia do wiedzy w odniesieniu do przyrody w ogóle. 
Zgodnie z porządkiem kategorii. A. Ilość materii.

A.

Wa ż k ość (ponderabilitas) tym różni się od ci ęż kości (ponderositas)2, że ta ostatnia oznacza większy ciężar w porównaniu z przeciętnym ciężarem innego [rodzaju materii] o tej samej objętości (volumen).

Ci ało jest pewną ilością materii o określonym kształcie (figurze), jeśli jest ona poruszana w masie; tj. wszystkie jej cząstki mają tę samą zdolność poruszania się, zajmowania pewnej matematyczno-cielesnej przestrzeni z jednakową prędkością i w tej samej chwili (jednocześnie).

Ilość materii może zostać poznana tylko [dzięki] vis acceleratrix wszystkich jej części, przez przyciąganie jakiegoś innego ciała jako ich siła przenikająca [tę materię]. Grawitacja nie jest żadnym specyficznym, ale powszechnym przyciąganiem i ma u swych podstaw pewien moment [pędu] jako prędkość początkową spadku [des Falles], który przy tej odległości i takiej samej ilości materii w przyciągającym c i e le, podczas całego spadku pozostaje niezmiennie ten sam i nie przechodzi przez różne momenty [pędu] (pod względem stopnia). Jako taka, prędkość wzrasta wprost proporcjonalnie do czasu, natomiast przebyta droga wzrasta proporcjonalnie do kwadratu prędkości (albo czasu).

Wielkość momentu grawitacji jest proporcjonalna do kwadratu odległości od ciała przyciągającego (rozpatrywanego jako punkt, w którym całą materię ciała przedstawia się jako skupioną), jeśli wysokość jego spadku w porównaniu z odległością od ciała centralnego może zostać uznana za nieskończenie małą.

W ruchu jednostajnie przyspieszonym spadek ciała pokonuje wszystkie stopnie prędkości - od tej, która w momencie (równym „0”) jest nieskończenie mała - przez wszystkie większe [od zera] momenty, które dają się pomyśleć jako zawarte pomiędzy chwilą początkową spadku aż po prędkość ostateczną; albowiem w przeciwnym razie nie byłby on motus uniformiter acceleratus.

Pytanie brzmi, czy moment przyciągania przy nieskończenie małej odległości, tzn. w styczności [bezpośredniej], która jest wówczas jedynie siłą powierzchniową, nie zawiera pewnej skończonej prędkości. Przy przyciąganiu

${ }^{2}$ [Przeciwstawienie terminów Wägbarkeit i Gewichtigkeit] 
równym odległości moment skończonej prędkości w dawałby nieskończoną prędkość nawet w najkrótszym czasie a, gdy np. drewniana tyczka albo żelazny drut, których części jedynie w styczności przyciągają się wzajemnie, zostaje zerwany przez zawieszony na nim ciężar, ściśnięcie tej materii przez jej własne wewnętrzne przyciąganie zmienia się w eksplozję o nieograniczonej prędkości. Ponieważ jest to niemożliwe, spójność materii, której moment przyspieszenia jest w stosunku do grawitacji nieskończony, nie może opierać się na wewnętrznej sile przyciągania materii, zwłaszcza grubość płytki (pozłoty) nie powoduje zmniejszonego przyciągania.

[prawy margines]

Ilość substancji może zostać oszacowana, ale nie na podstawie liczby jej części, ani objętości [volumen] (jeśli nie są one jednorodne), ani nawet przez zwykłe porównanie z innymi [substancjami], ale wyłącznie przez grawitację. Punkt materialny Laplace’a jest niemożliwością.

Fizyka (elementaris) jest nauką o wpływie [jednych] rodzajów materii na inne [materie], zachodzącym według praw powszechnych. Jeśli prawa te są tego rodzaju, że dotyczą one jedynie materii jako takiej, a więc że nie zakładają żadnego przedstawienia celów, to powstaje w ten sposób nauka elementarna [Elementarlehre] o przyrodzie, która zawiera w sobie nieorganiczne [XXI 407] wytwarzanie. Jeśli zaś są one takimi prawami, które - dla zrozumienia praw i możliwości wytworów przyrody - wymagają jednakże idei celów, to przyroda jest w tym przypadku rozpatrywana jako organiczna. Przy [rozpatrywaniu] owego przejścia uwzględniamy tylko to pierwsze.

Physica generalis nie jest postawiona obok physica specialis, ale jako physica elementaris obok physica specifica, w której różnorodne rodzaje powiązania materii zostają przedstawione nie jako elementy, ale jako wytwory [Fabricate] przyrody.

[na następnej stronie, tekst główny]

\section{Przedmowa}

Nauka o przyrodzie (philosophia naturalis) obraca się na dwóch zawiasach, z których jeden stanowią m et a fi zy c z n e, a zatem a priori połączone $\mathrm{w}$ jeden system podstawy, drugi natomiast zawiera ogólne, oparte 
na doświadczeniu, a zatem empiryczne zasady ich użycia w odniesieniu do przedmiotów zmysłu zewnętrznego, i który nazywamy fi z y ką .

Fizyka dzieli się następnie znowu na o gólną te orię fizyczną (physica generalis), która naucza jedynie o właściwościach m a t e r i i w zewnętrznych przedmiotach doświadczenia, a także taką [fizykę], która dotyczy ciał uformowanych $\mathrm{w}$ określony sposób $\mathrm{z}$ owej materii i tworzy $\mathrm{z}$ nich pewien system (physica specialis), np. rozważa różnicę pomiędzy ciałami nieorganicznymi i organicznymi.

Przejście [Übergang] od jednego systemu do innego systemu, jeśli nie wynika on z pokrewieństwa [między nimi], nie jest przejściem [Überschritt] (transitus), ale skokiem (saltus), który całkowicie niszczy to, co systematyczne, a zatem i naukowe w obrębie pewnej teorii i dlatego nie może być tolerowany w filozofii, która pragnie być niczym fizyka, ponieważ fragmentaryczne traktowanie swych przedmiotów nie pociąga za sobą żadnego związku pojęciowego i nie wytwarza całości [ujmowalnej] nawet dla pamięci.

Physica generalis zawiera zatem konieczność przejścia od metafizycznych podstaw przyrodoznawstwa do fizyki dzięki pokrewieństwu zachodzącemu pomiędzy regułami a priori i wiedzą o ich zastosowaniu do empirycznie danych obiektów, a które to przejście nie ogranicza się do pola, na które wkroczyło (czego dostarcza fizyka szczegółowa), ale jedynie określa podstawy postępu w tej nauce oraz w pełni je unaocznia.

Moje Metafizyczne podstawy etc. ${ }^{3}$ przeszły już część kroków na tym polu, ale jedynie dla przykładu możliwego zastosowania ich w obrębie doświadczenia, by to, co wypowiedziane w sposób abstrakcyjny, uczynić zrozumiałym za pomocą przykładów.

\section{I \\ Ilość materii}

Może ona zostać zmierzona jedynie dzięki ważeniu, tzn. ściskaniu elastycznej materii e.g. stalowej sprężyny, albo przede wszystkim za pomocą wagi (o ramionach jednakowej długości). Ciężar, który wskazuje ta ilość materii, jest naciskiem, którym ona [=ilość materii] oddziałuje dzięki temu, że jest przyciągana przez Ziemię jako ciało niebieskie. Ilość materii tego przyciągającego ciała niebieskiego [tzn. Ziemi] może zostać oszacowana jedynie za pomocą wychyleń wagi oraz liczby niewielkich łuków wykonywanych

\footnotetext{
${ }^{3}$ [tzn. Metafizyczne podstawy przyrodoznawstwa]
} 
przez nią zwrotów. Nie ma więc dla niej żadnego bezpośredniego miernika oprócz szacunków wyprowadzonych na podstawie wnioskowania. Tylko jej moment. Ten zaś z kolei jest różny w zależności od różnych wysokości, nie jest to specyficzna prędkość, ale powstaje ona podczas spadku [im Fall] ciała, wszystkie zaś ciała na ziemi (jeśli potraktujemy ją jako kulę) dzięki niej zawsze mają ten sam ciężar [Schweere], choć różną wagę [Gewicht]. Jest jednak wątpliwe, czy ciążenie [Schweere] w przypadku tego samego [ciała] zawsze pozostaje takie samo, ze względu na niedostrzegalne kurczenie się Ziemi i zmniejszający się jej promień, [nawet] jeśli okres obrotu Ziemi wokół własnej osi miałby pozostać stały. Owa grawitacja jest przyciąganiem na odległość, którego możliwości broniłem. Musiała ona być siłą przenikającą,

[XXI 409] ażeby każdy element materii z osobna i w całości został wprawiony w ruch. Ciężkość dowodzi wielkiej ilości materii w małej objętości. Czy zachodzi tu jakaś granica (w uniwersum), tego nie sposób się dowiedzieć. Platyna, jak dotąd, ma największą [ciężkość]. Absolutna lekkość byłaby materią pozbawioną wszelkiego ciężaru [Schwere], co przeczy pojęciu mobilis.

Ilość materii nie może zostać wywnioskowana na podstawie objętości ani dzięki żadnej określonej miary samej w sobie, ponieważ tylko przyciąganie całej masy przez grawitację może ją umieścić na tej samej wysokości z innym ciałem, określając ją relatywnie do innej materii (jako waga). Dlatego jedna szala wagi utrzymuje się na tej samej wysokości co druga [szala wagi], nie może zaś utrzymywać się równowaga, gdy jedna szala byłaby zawieszona milę wyżej od drugiej (tak samo jest z miarą przestrzeni), wszystko bowiem należy porównywać z [powierzchnią] ziemi. Niewielka kula, która wprawiła większą (całą Ziemię) w ruch ku górze z pewną prędkością, etc.

[prawy margines, dolna połowa]

W różnych odległościach ciała od punktu środkowego Ziemi istnieją różne momenty przyspieszenia, ale jeśli obierze się pewną wysokość nad powierzchnią Ziemi niezależnie od tego, jak bardzo byłyby od niej oddalone, w której różnica owych momentów może być uznana za nieistotną, np. wysokość jakiejś wieży, wtedy momenty te można uznać za równe, a kwadraty prędkości osiągniętych dzięki spadkowi są wprost proporcjonalne do wysokości spadku.

Gdyby przyciąganie wewnętrznej spójności w materii całkowicie i nagle mogło ustać, wówczas materia ta, rozszerzyłaby się nieskończenie, jeśli zaś ustałoby [wewnętrzne] odpychanie, skupiłyby się w jednym punkcie. 
[Następna strona tekst główny]

\section{II}

\section{Jakość}

[Materia] płynna, albo stała, sztywna. Ta pierwsza znów [musi] być albo rozszerzająco-płynna, za sprawą odpychania \{czy nie musi ona zostać przyjęta jako szczelna siła, ale dana jedynie dzięki pojęciu cząstek elementarnych[?]\} wszystkich swych wewnętrznych części, albo pr zy ci ąg a jąco-płynna wewnątrz obu. Materia ma tendencję do formowania się w kulę [zur Globosität]. P i e r w o t n e odpychanie byłoby [odpychaniem zachodzącym] bez ciepła. [Odpychanie wtórnie] p o ch o d zą c e z ciepła. Czy istnieje jakaś szczególna materia ciepła, albo czy istnieje czysto wewnętrzne poruszenie wszelkiej materii we wszechświecie[?] A jeśli istnieje to pierwsze, to czy materia ciepła musi być związana przez materię każdego innego rodzaju, ale w taki sposób, że jej część pozostaje niezwiązana [frey sey], by [możliwe było] rozszerzanie (i odczuwanie)[?]

Wszelka jedynie rozszerzająca się materia wydaje się zakładać ciepło jako przyczynę rozszerzającą. Czy zatem ciepło samo jest rozszerzającym się fluidum[?] Ponieważ wszelka płynność wymaga ciepła, powstanie wszelkich ciał niebieskich wymaga uprzedniego stanu płynnego, ten zaś obecnie jest utrzymywany przynajmniej przez światło słoneczne, więc materię ognia [das Feuerelement] można traktować jako poruszający wszystkie ciała i zawarty w ich wnętrzu rodzaj materii, który, za pośrednictwem ciepła i światła, jest przyczyną wszelkiej płynności.

\section{III}

\section{Wewnętrzna struktura}

a. O spójności płynnej materii w samej sobie, [o spójności materii] stałej z płynną, a w końcu [o spójności materii] stałej w samej sobie. W tej pierwszej relacji przyciąganie płynu na powierzchni określa jego kształt, w drugiej - [określa płyn] do wzniesienia się w rurce, albo na zewnątrz rurki (przy czym w obu przypadkach [rurka] jest ciałem stałym). W trzeciej - [określa] płyn do zejścia wewnątrz albo na zewnątrz rurki. 
b. W rozpuszczaniu materii ( $w$ formie stałej lub płynnej) oraz w osadzaniu się.

c. W krystalizacji i odparowywaniu

\section{Modalność}

Zasada poznania a priori is t n i e n i a $[D$ a s ei $n$ ] rzeczy (aktualność egzystencji), tj. doświadczenie w ogóle, zgodnie z całkowitym określeniem dyadyki ${ }^{4}$ leibniziańskiej: omnibus ex nihil ducendis sufficit unum, dzięki czemu wyłania się jedność wszystkich określeń w relacjach wszelkich rzeczy.

[lewy margines]

Nie istnieją dwie wzajemnie odpychające i przyciągające się cząstki jako względem siebie najbliższe materialne punkty, ale między każdym istnieje zawsze jeszcze inny punkt, a materia stanowi kontinuum.

W punktach położonych w różnych odległościach od centrum Ziemi są różne momenty przyspieszenia. Jednakże ruch uznany za jednostajnie przyspieszony, jeśli będzie powstawał na niewielkiej wysokości i gdy będzie zachodził z tym samym momentem [przyspieszenia], będzie [ruchem] odpychającym, albo itd.

Przyciąganie w styczności, dzięki któremu materia staje się stała, jest spójnością jako siła martwa. Moment przyciągania jest tu sk oń c z o n y i w najkrótszym czasie wywoływałby nieskończoną prędkość, gdyby mu nie przeciwdziałano.

A d h e z j a jest przemieszczającą się kohezją [tzn. spójnością], jak w przypadku gładkiej plano inclinatio ślizganie natrafia na przeszkodę, którą nazywa się tarciem i prowadzi do wygładzenia. Nawet powierzchnia o lustrzanej gładkości zawiera w sobie takie tarcie, które w wyniku stopniowego ścierania się wytraca materię stałą, poruszającego się i polerowanego ciała albo jego podłoża.

Sztywna powierzchnia [umieszczona] na dowolnej sztywnej, ale lustrzano-gładkiej powierzchni, stawia opór jej przesunięciu, jako momentowi uderzenia. Ale gutta cavat lapidem.

${ }^{4}$ [Określenie arytmetyki binarnej.] 
Ciała sztywne wzajemnie o siebie pocierane oddają ciepło. Czy może wszelkie ciepło nie jest jedynie stanem rozszerzania i wzajemnego przyciągania zachodzącego dzięki wibracjom[?] To, że wszelkie stałe i kruche ciała (szkło), chociaż powierzchnie ich pęknięcia pasują do siebie, nie mogą się już zbliżyć bardziej, jak tylko [umożliwiają to] siła powierzchniowa. Dlatego w postaci okruchów, podzielonych w taki sposób, że do siebie pasują, zajmują większą objętośćt.

Przełożył Tomasz Kupś

* Ilość [Quantum] materii jest mnogością poruszających się w przestrzeni, o ile łącząc się z sobą nawzajem i poruszając, tworzą pewną całość. Il o ść [Q u a n ti ät] jest określeniem tej mnogości jako pewnej jednorodnej całości. Wszelka materia jest pewną ilością [Quantum], tj. żadna materia nie powstaje z prostych części (punktów fizycznych). 